\title{
特集「法面自然回復緑化の現場をとりまく課題と展望（III)」 一自然回復緑化の実施現場からの声一
}

\section{自然回復緑化事例に基づく検查方法の提案}

\section{齋藤与司二 ${ }^{1)}$}

1）東京電力株式会社 建設部

\section{1.はじめに}

近年, 外来生物法 (2005 年), 第三次生物多様性国家戦略 (2007 年), 生物多様性基本法（2008 年）などが策定され, 希少な野生動植物の保全及び生物多様性の保全, 遺伝子資源 の保存と適正な利用方法が求められている。さらに, 人間と 自然のより望ましい共存関係を築いていくために, 自然のメ カニズム解明や生態系の保全, 地域特性を生かした取り組み などに重点が置かれるようになり, 自然回復緑化に取り組む 技術者にとってますますその重要性が高まってきている。

我が国における緑化事業の歴史は, 経済成長や環境問題な どと密接な関係があったものと推察され, 大規模開発に伴う 造成のり面や道路のり面などの緑化も大きく様変わりした。 1950 年代後半の高度経済成長期では外来草本を用いた急速 緑化工法, 1980 年代の経済安定期では生態系の早期回復及 び防災面に強いマメ科植物や先駆性樹種の採用, 1990 年代 は在来種（ここでは国外産在来種も含む）などを用いて景観 保全に有効な緑化方法等が取り入れられてきた。現在は，防 災や景観修復などのり面緑化工の目的をほぼ達成し, 生物多 様性保全に配慮して地域を限定した種による緑化方法等も見 られる。

地域遺伝子資源の観点からすると, 各々の樹種について地 域的な遺伝変異がどの程度あるのか, その遺伝変異の地理的 な分布がどのようになっているかという点に関しては DNA マーカーを用いた学術的な根拠づけが必要であるものの, そ の整理が不十分であるのが現状である。それにも関わらず， 全国において遺伝子污染が深刻となっている現状から判断す ると, 緑化現場での対策と学術的な根拠付けを並行して進め ていく必要がある。

本報告では, 東京電力が取り組んだ自然回復緑化事例の概 要を示し, これらの事例の経験を元に, 地域性系統種苗によ る緑化の取り組みが遅れている原因と解決すべき課題や今後 の検査のあり方について考察する。

\section{2. 自然回復緑化の取り組み事例}

\section{1 事例の概要}

東京電力が地域遺伝子資源保全の重要性を認識し, 自生種 によるのり面緑化に最初に取り組んだのは, $500 \mathrm{kV}$ 神流川
線建設工事である。この工事は, 群馬県上野村と長野県南相 木村に跨る送電線建設工事で，緑化対象面積は鉄塔敷（19 基)の 45,600 $\mathrm{m}^{2}$, 工事用道路のり面 12,600 $\mathrm{m}^{2}$ であった (図1)。次に取り組んだ事例は, 神流川揚水発電所建設工事であ る。この工事では, 長野県南相木村を流れる信濃川水系南相 木川の最上流部に南相木ダム及び群馬県上野村を流れる利根 川水系神流川の最上流部に上野ダムと 2 つのダムを建設し ている。この内, 南相木夕゙ムの緑化対象面積は, コア採取場 の $164,000 \mathrm{~m}^{2}$, 残土処理場の $68,000 \mathrm{~m}^{2}$ である（図-2）。

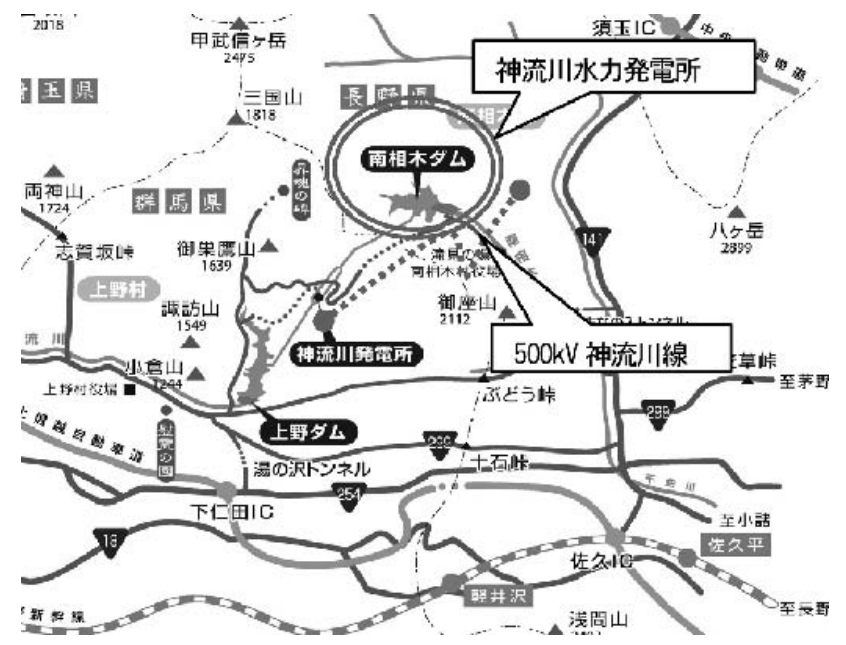

図-1 緑化対象位置図

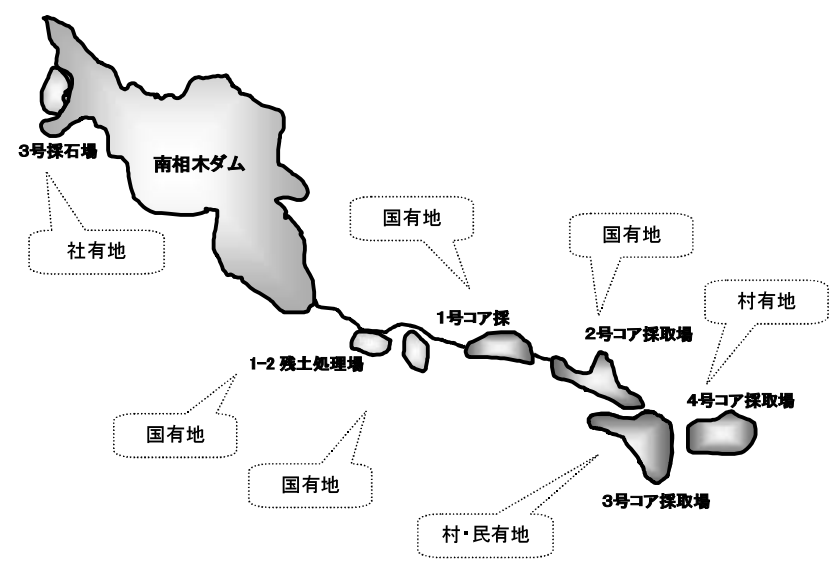

図-2 南相木ダム 緑化対象位置図 


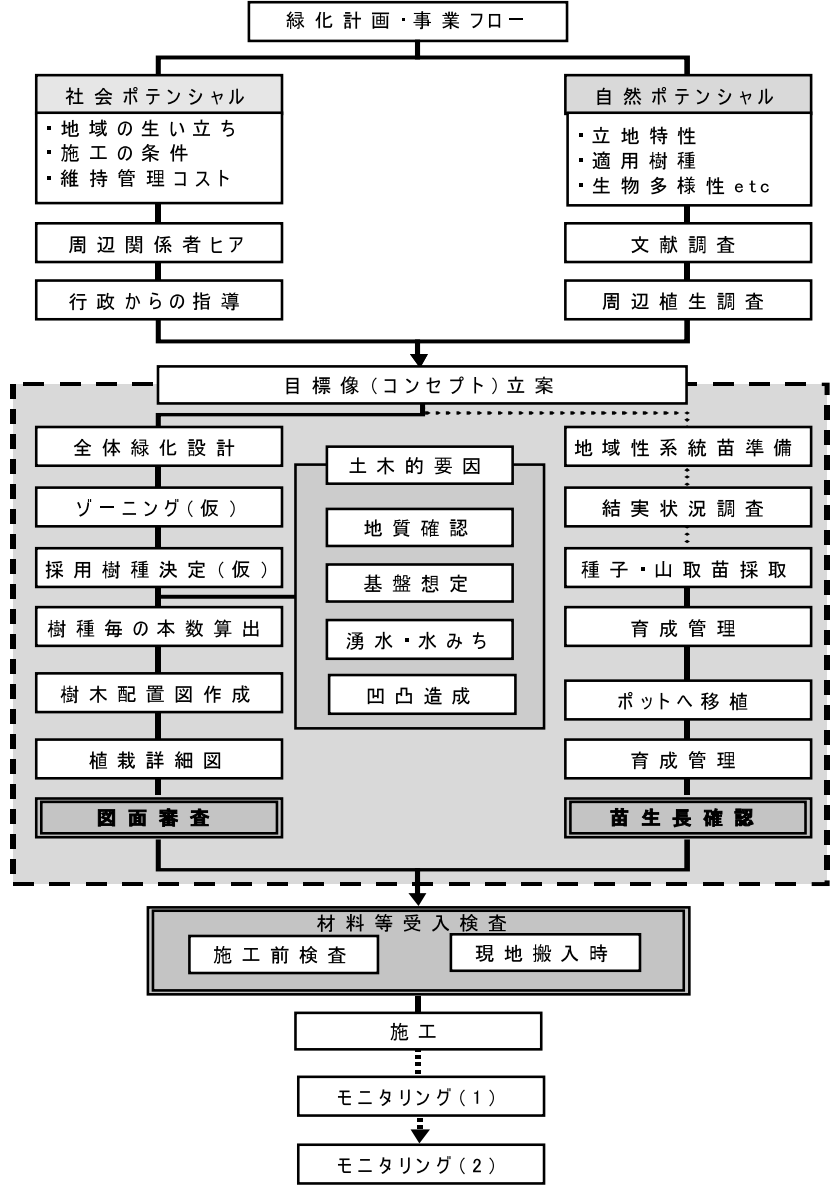

図-3 南相木ダム緑化計画・事業フロー

この 2 事例の気候的特徵は, 内陸性高冷地気候特有の寡 雪寒冷地で，年間平均気温は $6^{\circ} \mathrm{C}$ 前後，夏季も冷涼で昼夜 の気温較差が大きい。降水量は年間 $1,200 \mathrm{~mm}$ 前後で冬季の 降雪量は比較的少ない。

この 2 事例の緑化工事では，遺伝子污染に配慮するため に地域に自生する植物種子を利用して，自社で樹木の苗木を 育苗した。必要な苗木の総本数は，76 樹種，約 80,000 本で
あった。しかし，大規模な地域性系統苗の自主生産の経験が ほとんど無い。そこで，工事初期の基本計画の段階から，苗 木の育苗を考慮しながら，全体の緑化計画，立地ポテンシャ ル評価, 採用種子の選定, エリア毎の目標像, 将来目標の設 定，樹冠予測から生態系の広がりと時間的変化などについて 繰り返し調整や議論を重ね工事を進めてきた(図-3)。また, 現地試験工事の実施や，工事関係者に地域性種苗を利用する ことの大切さを理解してもらうための現地研修会を開催し た。

現地試験工事および本工事施工箇所においては，調査区を 設置して継続的なモニタリングを行っている。このモニタリ ング結果より特徴的な傾向を以下に記す。

2.2 モニタリングで得られた特徵的な傾向

（1）苗木の取扱い方（気候馴化の必要性）

高標高に生育する植物を低標高で育苗し, 気候馴化が不十 分な状態で苗を植えれば枯損することが想定される。そこ で，気候馴化による有效性を検証するため，現地仮植の越冬 苗（植栽前年の晚秋期に現地へ仮植した苗木）と植栽時現地 搬入苗（植栽の当年に現地へ搬入）で植栽後の苗木の生育状 況を調查したところ，生育に顕著な差が現れた。このような 過酷な気象条件下では, 植栽前の仮植は必須であることが示 唆された。

(2) 苗木の枯損原因と苗木の規格

本格的に植栽を開始したのは，2004 年 5〜7 月である。こ の植栽期間の気象状況は気温の平均值 $5^{\circ} \mathrm{C}$ を上回る記録的 な猛暑と空梅雨 (平均降雨量より $50 \mathrm{~mm}$ 少ない) であった が，一般的な緑化の苗木の枯損率 10〜20\% と比較して，当 地の苗木の枯損率は $0.4 \%$ と低かった（表-1）。さらに，集 中枯損や特定の樹種に限定して枯損が発生するという事象も なかった（写真-1）。

しかし，植栽 1 年経過後の 2005 年春季に実施した活着状 況調査では，一部のゾーンにおいて動物（シカ，ウサギ等） による食害被害が生じた（写真-2）。

また，度重なる積雪や融解の影響によって，幼苗の幹折れ や凍上害による倒伏，葉の変色等が見られた。ヤエガワカン

表-1２004～2005 年における植栽苗木本数及び枯損調査結果（2006 年〜 2 ヶ年のモニタリングより）

\begin{tabular}{|c|c|c|c|c|c|c|c|}
\hline \multirow{2}{*}{ 区分 } & \multirow{2}{*}{ 立地環境等 } & \multicolumn{3}{|c|}{ 地域性系統苗 } & \multicolumn{3}{|c|}{ 購入苗（カラマツ，ウラジロモミ他） } \\
\hline & & 植栽本数 & 枯損本数 & 枯損率（\%） & 植栽本数 & 枯損本数 & 枯損率 $(\%)$ \\
\hline A & レキ主体 & 18,664 & 39 & 0.21 & 5,106 & 1,658 & 32.47 \\
\hline B & レキ+細粒土 & 24,949 & 128 & 0.51 & 1,128 & 241 & 12.40 \\
\hline $\mathrm{C}$ & 細粒土主体 & 12,313 & 56 & 0.45 & 2,688 & 477 & 15.30 \\
\hline $\mathrm{D}$ & 湿潤地 & 1,076 & 3 & 0.28 & 216 & 33 & 6.80 \\
\hline $\mathrm{E}$ & 修景地 & 1,938 & 34 & 1.75 & - & - & - \\
\hline $\mathrm{F}$ & 小段部 & 4,857 & 27 & 0.56 & 882 & 49 & 5.60 \\
\hline G & 萌芽部 & 6,367 & 18 & 0.28 & - & - & - \\
\hline & & 70,164 & 305 & 0.43 & 10,020 & 2,458 & 10.37 \\
\hline
\end{tabular}




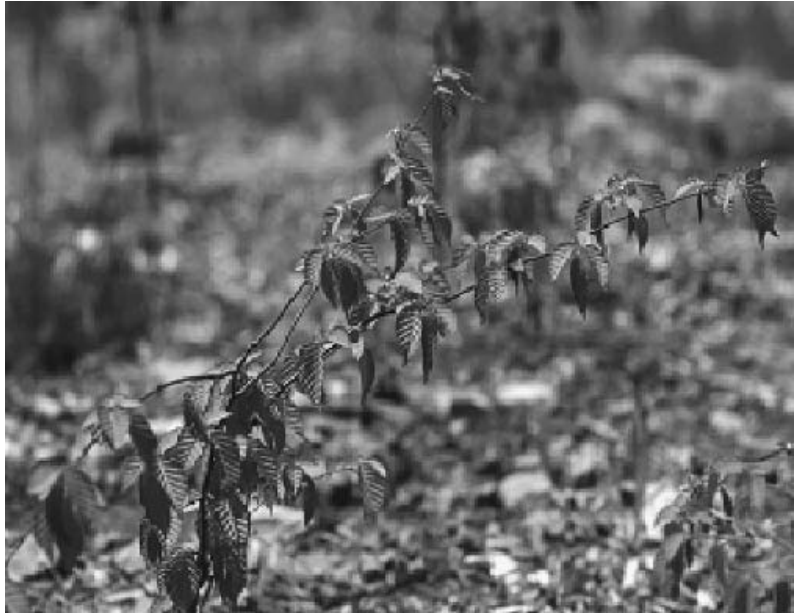

写真-1 1 年後の苗木生育状況（アカシデ）

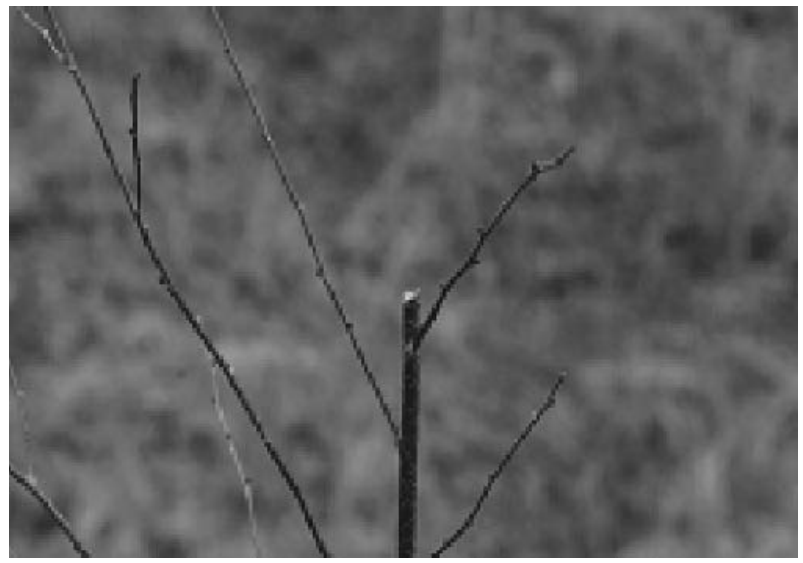

写真-2 食害を受けた苗木先端部

バなどは，冬季に幹折れしたものの萌芽再生し新しい葉が芽 生えている。寒冷地などの気象条件の厳しい環境下では, 苗 木の導入規格は樹高とともに幹の太さが重要であり，冬季の 凍結融解・積雪等に耐えられる一定以上の苗木幹周りの径が 必要ではないかと推察される。また, 萌芽性のある樹種につ いては，根系が良く発達していれば，一旦上部が折れても再 生可能であると推察される。

これらのモニタリング結果より，自主生産方式による苗 は，概ね 3 年生以上のものであれば枯損の確率が低く，適 用性が高いことが判った。また，苗木の樹高については，草 本類の被圧害を考慮して $70 \mathrm{~cm}$ 程度を目標として生産する こととした。なお，樹高 $70 \mathrm{~cm}$ 以下の苗を利用する場合は， 観察を行うとともに，雑草による被圧抑制として坪刈り等の 維持管理を行うこととした。

（3）生育基盤の整備と凍上対策

当地では，より多くの樹種が生育できるよう，客土工に よって多様性に富んだ地形(凹凸基盤)や磁を多く含む土壤， 細粒土を多く含む土畩を意眓的に造成している。この内, 細 粒土を多く含む土壤のエリアでは，地表面は一次緑化として 草本を播種し，その後，地域性系統苗を植栽した。しかし， 冬季の凍上に伴う土砂移動が生じた（写真-3）。土砂移動防

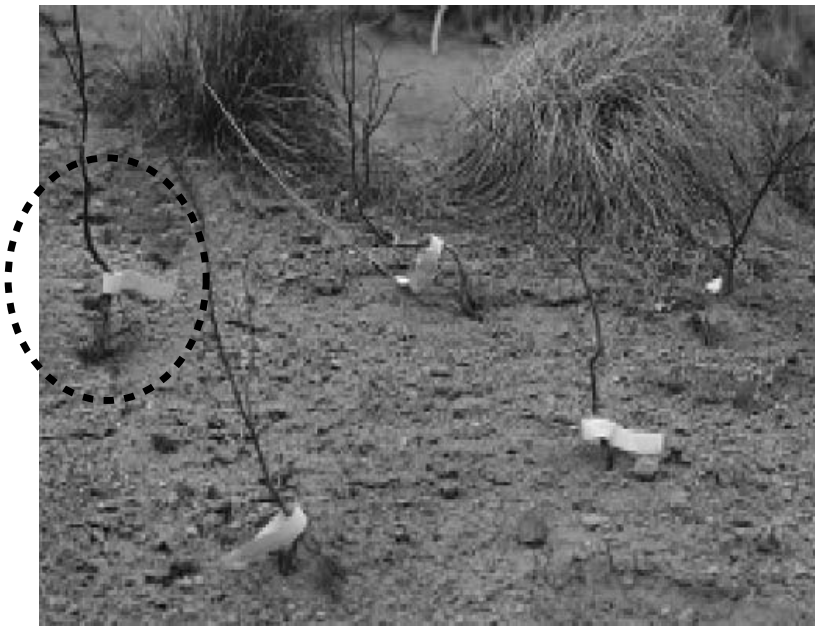

写真-3 凍結・融解による根の浮き上がり

止のために，夏場に刈り取った刈草を伏せる，細かに柵を設 ける，再度草本種を播種するなどの対策が必要であった。

\section{3. 自然回復緑化を通じた反省点と課題}

地域性系統苗を指向し，約 10 年間にわたって計画・試 験・工事・モニタリングを実施してきた。以下に，計画段 階，調査・育苗段階，工事 - 維持管理段階に区分し，各段階 の反省点や課題を整理した。

3.1 計画段階

地域遺伝子資源保全に重点を置き，行政に対して地域系統 種苗による緑化方法の提案を行った上で申請・手続きを行っ た。ところが，行政の了解を得るまで 6 ケ月を要した。こ の理由は, 審査・許可の行政と設計者の考え方や認識の相違 があったことである。特に自然回復緑化に関する認知度が低 いことが大きな課題である（表-2）。

\section{2 調査・育苗段階}

調査・育苗段階での反省点は種子採取の問題である。文献 や現地調查を基に，概略の緑化設計を行い，緻密な種子採取 計画に基づき進めてきたが，結実調査年と種子採取年が異な ることや種子の豊凶等もあって, 樹種毎の目標数量が確保で きなかった。この反省点は，次候補の樹種についても検討 し, 適宜, 数量管理を行い, その都度緑化計画の修正と代替 案を考える必要がある。

次に，自主生産方式により育苗した 76 樹種，約 80,000 本の苗木規格の問題である。寡雪寒冷地における適正な苗木 規格は, 基本的に 3 年生以上, 幹径 $1 \mathrm{~cm}$, 樹高 $70 \mathrm{~cm}$ 程度 以上は必要と考えている。また，高標高寒冷地での植栽で は，導入苗木の樹高よりも品質の良く根系の発達した苗（T/ $\mathrm{R}$ 比のバランスの良いもの）で，積雪接線面が木質化してい ることが重要である。

これまで，植栽した 76 樹種に関しては，既往の文献など によって樹種の生育特性を知ることはできるが，発芽および 初期生育に関するデー夕は皆無で, かつ育苗経験もなかった ことから，幼苗の年間生長量を予測することができなかっ た。このため, 一部の樹種については目標とする $70 \mathrm{~cm} の$ 
道路工事 のり面緑化の計画及び設計段階における設計者と行政の見解の相違

協議項目

1) 自然回復に関する理解 度 $\cdot$ 認知度

(2) 全体のコンセプトと手法

3) 使用する緑化植物材料

(4) 具体的な自生種等の組み 合わせと種類

(5) 緑化基礎工

設計者

自然回復緑化を指向した計画。

侵食防止を図りつつ，地域の生態系や遺伝子資 源の保全を図る。

地域が育んできた歴史や文化等に関する調査を 実施し, 地域にふさわしい緑化計画の提案を実 施した。

周辺地域から種子・山取苗等を採取し, 自生種 による植物材料の提案を実施。

遷移中期・後期の樹種の生長環境を鑑み, 採用 する樹種は強光・弱光を考慮し自生種と先駆性 樹種との組み合わせを提案。

斜面の状態を観察し必要と判断された箇所のみ 菱形金網張工にすることを提案。
何故，この現場で新しい試みをするのか，試験 ヤードではない。

新しい試みをするのであれば他（他地域）で実 施してほしい。

針葉樹を中心とした林地回復を行ってほしい。

従来の緑化方法(マメ科のハギ類等)でも良い。

ヤマハンノキ，ヤシャブシ等の先駆性樹種は倒 木の原因となるため採用を控えること。

緑化基礎工は必要であり，のり面全てに適用す ること。

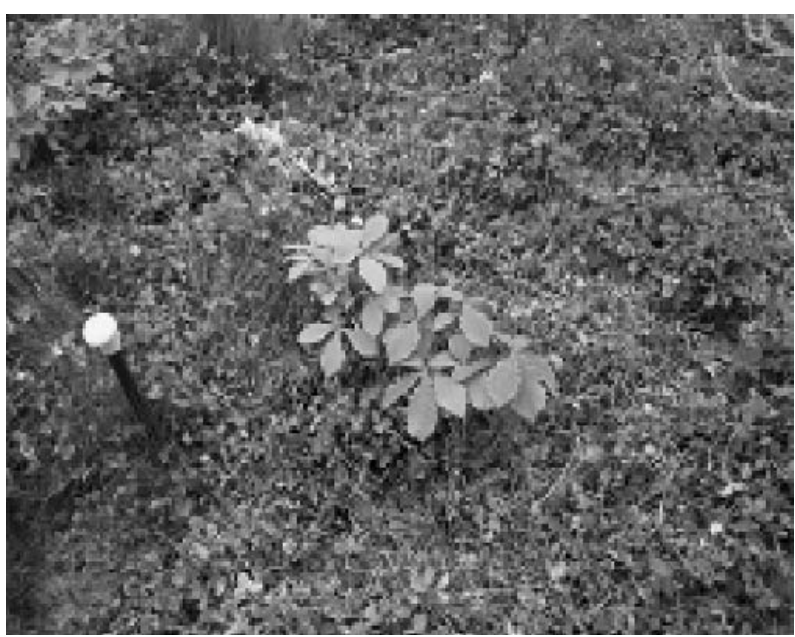

写真-4 目標に達しなかった $20 \mathrm{~cm}$ の幼苗

樹高まで育苗することができず，工事の工程上，樹高 $20 \mathrm{~cm}$ や $30 \mathrm{~cm}$ の状態で植栽する場面が生じた(写真-4)。今後は, 初期生長を予想した上で， 2 年生苗の樹種， 3 年または 4 年 生苗の樹種に区分し，よりきめ細かな育苗計画及び全体工程 に余裕を持った育苗期間を設定する必要がある（表-3）。

3.3 工事・維持管理段階

工事における反省点は，まず，多様性のある植栽基盤を目 標に，現地発生の巨砂を縞状に配置し基盤造成を行なったと ころ，地中に間隙が多い基盤を作ったことによりネズミの大 量発生を招いてしまった。また，シカによる苗木の食害防止 を目的に設置したフェンスは，2006 年の冬期に約 100 箇所 破られていた（写真-5)。一旦，シカが侵入すると，破損筒 所が急増する。一部の植栽エリアでは，植栽苗木の 7 割が 幹をかじられる被害を受けた。しかし，後の調査ではその内 8 割程度は枯損せず，新しい葉や幹が萌芽した。さらに，側 溝から侵入したと思われるウサギの食害も多く確認された。
表-3 地域性系統苗と購入苗の生育傾向の違いと樹勢

\begin{tabular}{|c|c|c|c|}
\hline & 地域性系統苗 & 購 入 苗 \\
\hline \multicolumn{2}{|c|}{ 苗の規格 } & 樹高が小さく，一般の規 & 規格に適合した苗 \\
\hline \multirow{3}{*}{$\begin{array}{l}\text { 生育 } \\
\text { 傾向 }\end{array}$} & 樹形 & $\begin{array}{l}\text { 樹幹の下部が大きく安定 } \\
\text { した樹形 }\end{array}$ & $\begin{array}{l}\text { 樹幹の上部が大きく } \\
\text { 不安定な樹形 }\end{array}$ \\
\hline & 樹勢 & 葉色が良好で樹勢が良好 & $\begin{array}{l}\text { 葉色が悪く樹勢が不 } \\
\text { 良 }\end{array}$ \\
\hline & その他 & $\begin{array}{l}\text { 気象害（強風, 積雪害) } \\
\text { に対する抵抗力が強い傾 } \\
\text { 向が見られ。 } \\
\text { 植栽 } 2 \text { 年目から地際から } \\
\text { 旺盛な萌芽が見られた。 }\end{array}$ & $\begin{array}{l}\text { 気象害（強風, 積雪 } \\
\text { 害）に対する抵抗力 } \\
\text { が弱い傾向が見られ } \\
\text { る。 }\end{array}$ \\
\hline
\end{tabular}

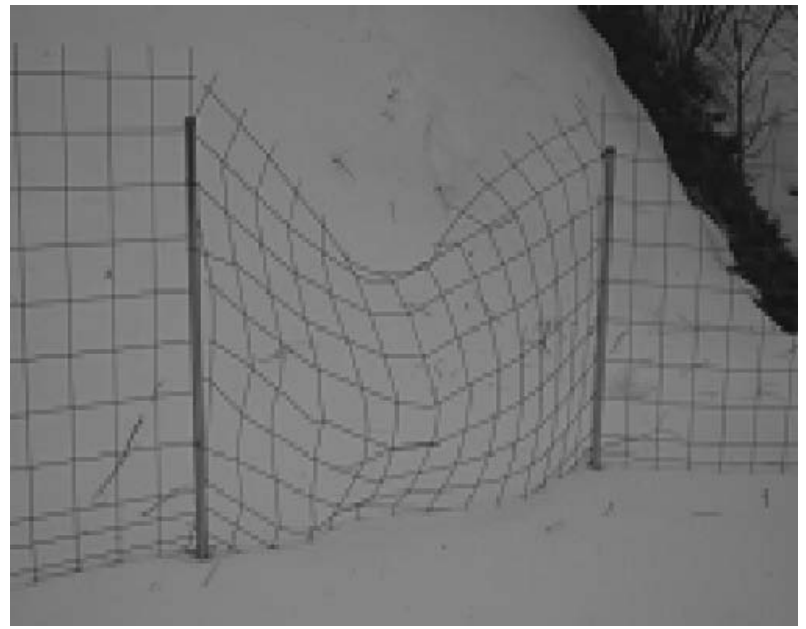

写真-5 シカに破られたフェンス

\section{4. 今後の自然回復の検査の考え方（提案）}

これまでに得られた知見や反省点を踏まえ， $\mathrm{S}$ 県に建設の 


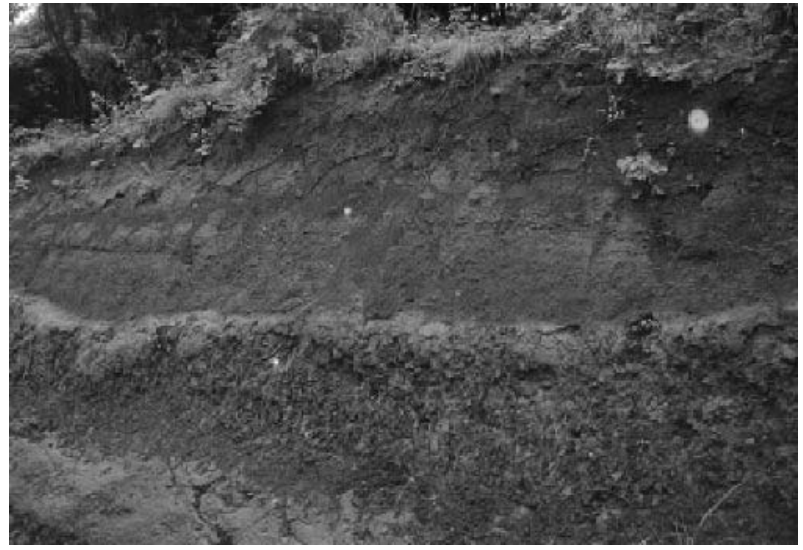

写真-6 ローム層で法尻にのみ活着し遷移は難しい

新規道路（総延長 $10.2 \mathrm{~km}$ ，幅員 $4.5 \mathrm{~m} ， の り$ 面の面積 $120,000 \mathrm{~m}^{2}$ ， I 期工事 $5.6 \mathrm{~km} ，$ の面の面積約 $82,000 \mathrm{~m}^{2}$ ) の緑化計画を進めている。

この新規道路緑化計画では，自然回復緑化を指向し，早期 段階から地域性系統苗及び種子採取計画を立案し, 全て社給 品として対応する。この新規道路緑化のコンセプトは,「自 然環境に配慮しつつ，永続的な斜面安定と地域固有の景観環 境の維持」とした。具体的には, 生態系保全及び遺伝子資源 保全ゾーン，自然景観保全（周辺自然との同化）ゾーン，侵 食防止重視ゾーンの大きく 3 ゾーンに区分し，設計者とし てのり面緑化工の目的及び目標を明確にした。また，緑化工 事仕様書，積算体系の大幅な見直しを図り，検査方法等につ いても改善を図った。

作成段階の緑化工事仕様書では，これまで配置しなかった 緑化に関する専門技士を配置し, 積算へも反映している。緑 化植物材料は，全て弊社育成苗及び採取した種子を支給す る。施工に際しては，苗や種子の配置図を作成し，現地にて 立ち会い後, 施工する。また, のり面の吹付では厚さの管理 に重点が置かれてきたが，ブロック毎に調査を行い，吹付量 (バッチ) による管理とする。なお，バッチ管理に際しては 現地立ち会いを原則とした。緑化基礎工のうち菱形金網張工 は，地域性種苗の生育の妨げとなることから実施しない。表 面侵食及び肌落, 滑落が予想される箇所については現地立ち 会いで判断し採用する場合がある。

また，切土のり面造成の仕上げは凹凸仕上げを原則とし， 平滑仕上げは行わない。検查については原則行わないことと した。検査ありきの時代から, 発注者や受注者, 関係者がと もに後世に誇れる緑づくりを目指すこととし, 施工 3 年後 ののり面状態や活着状況を確認する程度とした。

残念なことに, 近傍で先行して実施した道路工事の緑化 は, ずさんな状況にあり, 本計画の道路の許認可は影響を受 けることになる（写真-6, 写真-7）。

昨今, 各学会をはじめ産学官等が連携し, 持続可能なイン フラ整備のあり方や, 開発に扔ける影響緩和策について真剣 に取り組んでいる中で，このように無秩序な緑化のり面が現 存することに驚きを覚える。当該のり面が再施工されずに見

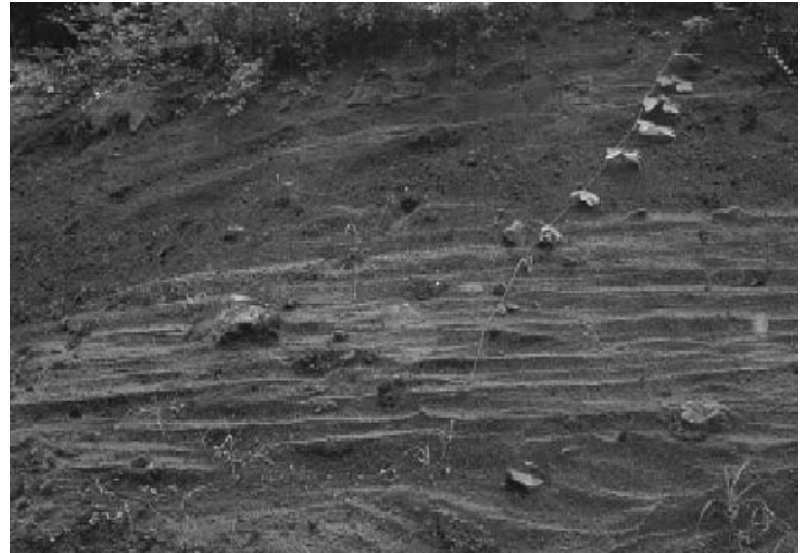

写真-7 植生の侵入がなく, 硬度差の波型剥離を形成

過ごされるとすれば，計画申請さえ許可されれば事後の検査 も行われず，罰則規定もない現状の許認可制度は大きな問題 があると言えよう。

特に, 後発事業者の計画申請書を厳しくすることで事態を 改善しようとするのが多くの考え方で, 計画申請の許可が無 為に長い時間を要するとともに様々な許可条件が付加され, 後発事業者の経費増大を招いていることになる。

最後に, 当該施工のり面がこのまま粗放されることなく, 必ずや手直しが行われることを願ってやまない。

\section{引用文献}

1）環境省自然保護局ほか（2006）平成 17 年度外来生物によ る被害の防止等に配慮した緑化植物取扱方針検討調査委託 業務報告書, $283 \mathrm{pp}$.

2）環境省自然保護局ほか（2007）平成 18 年度生態系保全の ための植生管理方策及び評価指標検討調查（生態系保全の ための植生管理方策検討調查) 報告書, $217 \mathrm{pp}$.

3）日本緑化工学会（2002）生物多様性保全のための緑化植物 の取り扱い方に関する提言, 日本緑化工学会誌, 27(3): 481-491.

4) 日本緑化工学会斜面緑化研究部会（2004）のり面における 自然回復緑化の基本的な考え方のとりまとめ, 日本緑化工 学会誌, 29(4): 509-520.

5）日本緑化工学会斜面緑化研究部会（福永健司・吉田寛 - 山 田守・中野裕司・西澤睦博）（2008）特集「のり面自然回 復緑化の現場をとりまく課題と今後の展望」一四省庁によ る「緑化植物取扱方針」の推進にあたって一, 日本緑化工 学会誌, 33(3): 453-473.

6) 日本緑化工学会斜面緑化研究部会 - 積雪寒冷地緑化研究部 会（2008）第 1 回合同研究会報告 積雪寒冷地における自 然回復緑化一地域生態系に配慮した“のり面保全” への取 組み一，日本緑化工学会誌，33(4): 614-619

7）齋藤与司二 ・ 中山和雄・吉永剛 - 等々力敏樹ほか (2005) 生物多様性の高い森林復元を目指した自主生産地域性苗木 の導入について (その 2), 第 36 回日本緑化工学会研究発 表会研究発表要旨集：179-182.

8）齋藤与司二 ・上條勝彦・等々力敏樹（2007）寒冷地におけ る地域性系統緑化手法の導入と課題, 日本緑化工学会誌, $32(3)$ : 421-424 